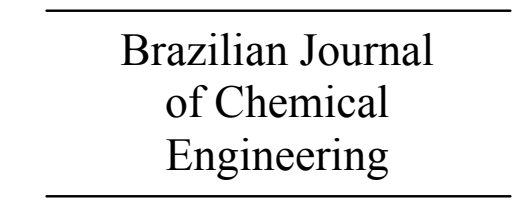

ISSN 0104-6632

Printed in Brazil

Vol. 21, No. 02, pp. 165 - 173, April - June 2004

\title{
THE EFFECT OF MEDIUM COMPOSITION ON INTERLEUKIN-2 PRODUCTION BY MURINE EL-4 THYMOMA CELLS
}

\author{
A. L. L. Galesi ${ }^{1}$, W. M. S. C. Tamashiro ${ }^{2}$ and A. M. Moraes ${ }^{1}$ \\ ${ }^{1}$ Departamento de Processos Biotecnológicos, Faculdade de Engenharia Química, \\ Universidade Estadual de Campinas, 13083-970, Campinas, SP - Brazil. \\ E-mail: ammoraes@feq.unicamp.br \\ ${ }^{2}$ Departamento de Microbiologia e Imunologia, Instituto de Biologia, \\ Universidade Estadual de Campinas, 13083-970, Campinas, SP - Brazil. \\ E-mail: wirlatam@unicamp.br
}

(Received: February, 13, 2003 ; Accepted: December 8, 2003)

\begin{abstract}
Due to the role of interleukin-2 (IL-2) in the mediation of immune response, this cytokine has been used in the treatment of some types of cancer and infectious diseases. However, relatively high levels of this cytokine are required to achieve significant activity. The aim of this work was to study a culture medium composition designed to increase the production of IL-2 by suspended murine EL-4 cells. The cultivations were carried out aiming at producing IL-2 in stirred bioreactors. The effects of concentration of glutamine, phorbol-12-myristate-13-acetate (PMA), concanavalin A (Con A), Pluronic F68, and fetal calf serum (FCS) on cell viability and IL-2 production were evaluated. PMA alone was more efficient in IL-2 production than it was in association with Con A. The maximum IL-2 production was around $162 \mathrm{ng} / \mathrm{mL}$ with $856 \mathrm{ng} / \mathrm{mL}$ PMA and $1.45 \%(\mathrm{v} / \mathrm{v})$ FCS.

Keywords: cytokine, bioreactors, interleukin-2.
\end{abstract}

\section{INTRODUCTION}

The administration of high-dose recombinant interleukin-2 (IL-2) to humans has been reported to mediate the regression of some types of cancer, such as kidney cancer, melanomas and non-Hodgkin's lymphoma (Rosenberg et al., 1985a; 1985b; Weinreich and Rosenberg, 2002). Although IL-2 has no direct effect on tumor cells, this cytokine has the ability to expand lymphocytes with anti-tumor activity in vivo. However, toxicity and adverse side effects, such as vascular leak syndrome and elevated serum cortisol levels (Stites et al., 1994), occur at pharmacological IL-2 dosages, which vary from picomolar to nanomolar concentrations in serum (Fehniger et al., 2002). These effects should be evaluated more extensively, which can be initially done through experiments with animal models, such as mice.

Although IL-2 is naturally secreted in low quantities by naturally activated $\mathrm{T}$ lymphocytes (Walsh and Headon, 1994), the culture of other cell lines, such as tumor and recombinant cells, can result in higher IL-2 concentrations. A lymphoblast cell line isolated from a murine thymus tumor, referred to as EL-4 (Farrar et al., 1980), has been extensively employed to study the production of IL-2 in vitro. The IL-2 produced by those cells can be utilized in tests in vivo, using mice as animal models, since it is biochemically and biologically indistinguishable from that produced by healthy mice (Chang et al., 1985).

It has been shown that phorbol-12-myristate-13acetate (PMA) and/or concanavalin A (Con A) 
stimulate EL-4 cells to produce high levels of the cytokine in the culture supernatants (Farrar et al., 1980; Lasek et al., 1989), mimicking the effects of a specific antigen on the thymoma cells. The effects of other cell stimulants, such as vomitoxin, cycloheximide (Dong et al., 1994), and vitamin E succinate (Yu et al., 1996) on IL-2 production by EL-4 cells have also been evaluated. However, few data are available on the effects of medium components and their metabolites on EL-4 cell growth as well as on IL-2 production by those cells.

In this work, the effects of glutamine concentration (carbon and nitrogen source), PMA and Con A concentrations (IL-2 production stimulants), percentage of Pluronic F68 (an additive protecting cells against shear damage), percentage of FCS (additional nutrients), and cell inocula were evaluated, aiming at a high level of production of IL2. The experimental design strategy, which has not as yet been extensively applied to mammalian cell culture, was used.

\section{MATERIALS AND METHODS}

\section{Materials}

EL-4 lymphoblasts were kindly donated by Dr. João Santana da Silva (Departamento de Imunologia, Faculdade de Medicina, Universidade de São Paulo, Ribeirão Preto, SP - Brazil). Cells were cultured in RPMI-1640 medium containing gentamicin (50 $\mu \mathrm{g} / \mathrm{mL}$ ) and different concentrations of L-glutamine, PMA, type IV-S Con A, Pluronic F68 (Sigma Chemical Co.), FCS (Cultilab), and dimethylsulfoxide (Merck). Medium compositions employed in the different experiments are described in Tables 1, 2, and 3. The cells were grown in $25 \mathrm{~cm}^{2}$ tissue culture polystyrene flasks (Corning) and cultured for IL-2 production in six-well polystyrene culture plates (Costar). The cells were incubated for $40 \mathrm{~h}$ at $37^{\circ} \mathrm{C}$ in a humidified chamber with $5 \% \mathrm{CO}_{2}$.

\section{Preparation of the Inocula}

EL-4 cells were grown in RPMI-1640 medium (detailed composition described by Freshney, 1994) supplemented with $10 \%(\mathrm{v} / \mathrm{v})$ FCS to obtain the inocula. When 60 to $80 \%$ of the culture flask was occupied, cells were subcultured. When sufficient cell concentration was obtained, cell suspension was centrifuged and the pellet was suspended in RPMI1640 medium without FCS.

\section{Experimental Design}

The effects of the variables glutamine concentration, PMA concentration, percentage of Pluronic F68 (w/v) and percentage of FCS (v/v), and initial cell concentration were studied to evaluate the influence of culture medium composition and inocula concentration on cell growth, viability, and IL-2 production after 40 hours. These effects were analysed employing a $2^{5-1}$ factorial experimental design with three replicates at the center point in a total of 19 experiments, employing RPMI-1640 supplemented with $50 \mu \mathrm{g} / \mathrm{mL}$ of gentamicin as the minimal media. The variables whose effects had statistical significance were studied in a second experimental design. A third experimental design was used to evaluate the effects of Con A on IL-2 production.

\section{Determination of Cell Concentration and Viability}

Cell concentration was determined by optical microscopy with the use of a hemocytometer. Viable cells were determined by Trypan Blue exclusion (Freshney, 1994).

\section{Determination of Interleukin-2 Concentration}

IL-2 concentration was determined by immunoassay, employing the M2000 Mouse IL-2 Quantikine M kit (R\&D Systems). The assays were conducted essentially as suggested by the manufacturer. Briefly, all reagents were brought to room temperature and $50 \mu \mathrm{L}$ of assay diluents were added to each well of a 96-well microplate coated with polyclonal antibody specific to mouse IL-2. Fifty $\mu \mathrm{L}$ aliquots of standards, controls, and adequately diluted samples were added to each well. The microplate was gently shaken, covered, and incubated for two hours at room temperature. The wells were vacuumed and washed five times with the buffer provided by the manufacturer. Following this procedure, $100 \mu \mathrm{L}$ of a solution containing an antibody against mouse IL-2 conjugated to horseradish peroxidase were added to each well. The plate was covered, incubated for two hours at room temperature, aspirated, and washed five times. Subsequently, $100 \mu \mathrm{L}$ of substrate (stabilized hydrogen peroxide) were added to each well and the plate was incubated at room temperature for 30 minutes, after which the reaction was interrupted by the addition of $100 \mu \mathrm{L}$ of diluted hydrochloric acid solution. The optical density at $450 \mathrm{~nm}$ was read on a 
Labsystems Multiskan MS after 30 minutes, with the correction wavelength set at $540 \mathrm{~nm}$ to correct for optical imperfections in the plate.

\section{RESULTS AND DISCUSSION}

Effects of Cell, Glutamine, PMA, Pluronic F68, and FCS Concentrations on Cell Viability and IL2 Production

The influence of PMA, glutamine, and cell concentrations, and percentage of Pluronic F68 (w/v) and percentage of FCS $(\mathrm{v} / \mathrm{v})$ on cell viability and IL2 production after $40 \mathrm{~h}$ incubation were studied using a $2^{5-1}$ factorial experimental design with three replicates at the center point. The minimum medium (RPMI-1640 containing $50 \mu \mathrm{g} / \mathrm{mL}$ of gentamicin) was supplemented with the above-mentioned compounds. Table 1 shows the experimental design with the ranges for each variable and the results obtained. IL-2 concentration varied from 0 to 98 $\mathrm{ng} / \mathrm{mL}$, showing the importance of culture medium formulation for large-scale production of IL-2. Larger IL-2 concentrations were obtained when the initial cell concentration was $1.0 * 10^{6}$ cell $/ \mathrm{mL}$. Experiments 14 and 16 showed the best results for IL-2 production.

The contrasts of the independent variables on the response variables (shown in Figure 1) were calculated using the software Statistica. The variables that were statistically significant at a confidence level of $95 \%$ on IL-2 production were PMA and cell concentrations and percentage of FCS. An increase in these variables caused an increase in IL-2 concentration. This result was expected, since PMA is a stimulant of IL-2 production and FCS is an essential component of the cell culture, stimulating cell growth and other cell activities through hormones and growth factors.

Table 1: $2^{5-1}$ factorial experimental design with three replicates of the center point. The minimum medium formulation was RPMI-1640 supplemented with $50 \mu \mathrm{g} / \mathrm{mL}$ of gentamicin.

\begin{tabular}{|c|c|c|c|c|c|c|c|}
\hline Exp. & $\begin{array}{c}\text { PMA } \\
\text { (ng/mL) }\end{array}$ & $\begin{array}{c}\text { Pluronic } \\
\text { F68 } \\
(\%)\end{array}$ & $\begin{array}{l}\text { FCS } \\
(\%)\end{array}$ & $\begin{array}{c}\text { Glutamine } \\
(\mathrm{g} / \mathrm{L})\end{array}$ & $\begin{array}{c}\text { Initial cell } \\
\text { concentration } \\
(\text { cells } / \mathbf{m L})\end{array}$ & $\begin{array}{c}\text { IL-2 } \\
\text { concentration } \\
(\mathrm{ng} / \mathbf{m L})\end{array}$ & $\begin{array}{c}\text { Cell } \\
\text { viability } \\
(\%)\end{array}$ \\
\hline 1 & 10 & 0.0 & 0 & 0.60 & $0.10^{*} 10^{6}$ & 0.10 & 100 \\
\hline 2 & 100 & 0.0 & 0 & 0.30 & $0.10^{*} 10^{6}$ & 1.13 & 75 \\
\hline 3 & 10 & 0.2 & 0 & 0.30 & $0.10 * 10^{6}$ & 3.64 & 77 \\
\hline 4 & 100 & 0.2 & 0 & 0.60 & $0.10 * 10^{6}$ & 9.61 & 60 \\
\hline 5 & 10 & 0.0 & 10 & 0.30 & $0.10 * 10^{6}$ & 6.75 & 75 \\
\hline 6 & 100 & 0.0 & 10 & 0.60 & $0.10^{*} 10^{6}$ & 13.20 & 62 \\
\hline 7 & 10 & 0.2 & 10 & 0.60 & $0.10^{*} 10^{6}$ & 12.62 & 68 \\
\hline 8 & 100 & 0.2 & 10 & 0.30 & $0.10 * 10^{6}$ & 15.96 & 61 \\
\hline 9 & 10 & 0.0 & 0 & 0.30 & $1.00 * 10^{6}$ & 0.00 & 63 \\
\hline 10 & 100 & 0.0 & 0 & 0.60 & $1.00 * 10^{6}$ & 0.89 & 71 \\
\hline 11 & 10 & 0.2 & 0 & 0.60 & $1.00 * 10^{6}$ & 3.08 & 69 \\
\hline 12 & 100 & 0.2 & 0 & 0.30 & $1.00 * 10^{6}$ & 28.89 & 71 \\
\hline 13 & 10 & 0.0 & 10 & 0.60 & $1.00 * 10^{6}$ & 27.39 & 62 \\
\hline 14 & 100 & 0.0 & 10 & 0.30 & $1.00 * 10^{6}$ & 66.24 & 48 \\
\hline 15 & 10 & 0.2 & 10 & 0.30 & $1.00 * 10^{6}$ & 11.88 & 69 \\
\hline 16 & 100 & 0.2 & 10 & 0.60 & $1.00 * 10^{6}$ & 97.99 & 52 \\
\hline 17 & 55 & 0.1 & 5 & 0.45 & $0.55 * 10^{5}$ & 39.69 & 50 \\
\hline 18 & 55 & 0.1 & 5 & 0.45 & $0.55 * 10^{5}$ & 56.62 & 56 \\
\hline 19 & 55 & 0.1 & 5 & 0.45 & $0.55 * 10^{5}$ & 42.78 & 57 \\
\hline
\end{tabular}




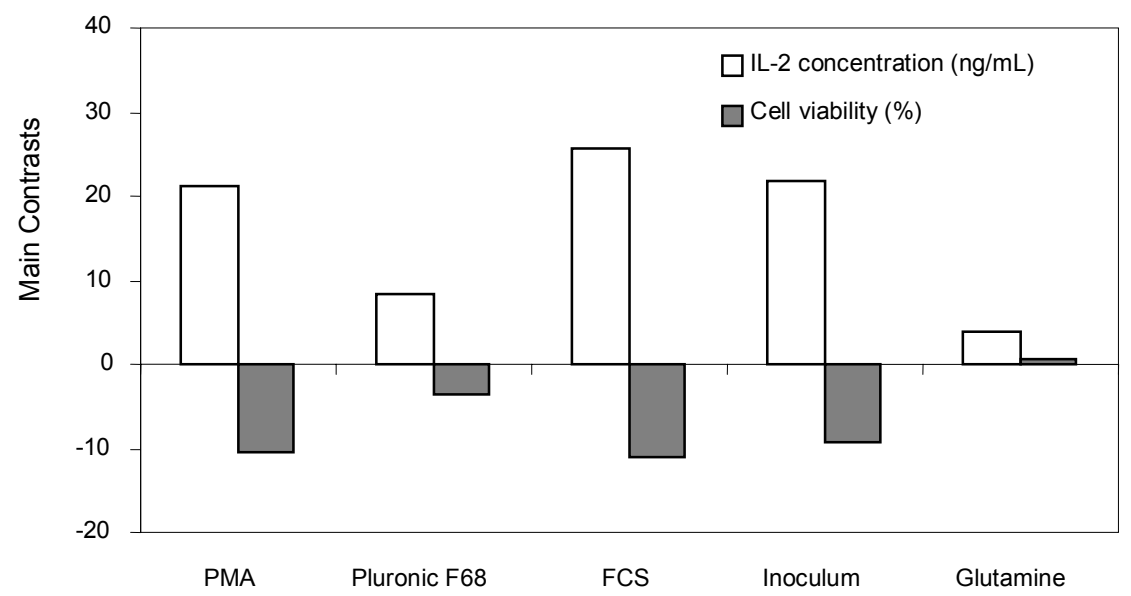

Figure 1: Main contrasts obtained for the $2^{5-1}$ factorial experimental design on cell viability and IL-2 concentration. The minimum medium formulation was RPMI-1640 supplemented with $50 \mu \mathrm{g} / \mathrm{mL}$ of gentamicin. * indicates that the variable is statistically significant at a confidence level of $95 \%$.

However, increases in PMA, FCS, and cell concentrations resulted in a significant reduction in cell viability at a confidence level of $95 \%$. Since phorbol esters are thought to promote cell survival and protection against cell death by activation of PKC-dependent signaling pathways, the decrease in cell viability with the increase in PMA concentration should be attributed to a possible inhibitory effect of this compound on the interaction of IL-2 with its receptor on the cell surface (Farrar et al., 1980).

The paradoxal effect of FCS on cell viability may be attributed to an indirect effect of the long culture time, since FCS is not expected to decrease cell viability. After the 40-hour culture period, the culture medium was probably depleted of nutrients and already accumulating toxic metabolites such as ammonium and lactate, which could be present at higher concentrations in the samples originally containing more serum. However, this hypothesis was not tested.

Pluronic F68 and glutamine did not have a significant effect on cell viability and IL-2 production in the concentration ranges studied. Since Pluronic F68 is an agent that protects cells against shear damage, its concentration in the culture medium was maintained at $0.2 \%$ in the following experiments, whereas glutamine concentration was fixed at $0.3 \mathrm{~g} / \mathrm{L}$ to minimize costs.

Generally, cultures initiated with $1.0^{*} 10^{6}$ cell $/ \mathrm{mL}$ inocula yielded higher levels of IL-2 than those starting at $1.0 * 10^{5}$ cell $/ \mathrm{mL}$. This finding was more evident when large concentrations of PMA (505 $\mathrm{ng} / \mathrm{mL}$ ) were used. In this circumstance, the increase in IL-2 formation was closely associated with the abbreviation of the cell growth lag phase. Figure 2 summarizes the behavior of a cell culture starting at $1.0 * 10^{6}$ cell $/ \mathrm{mL}$ and shows that IL-2 formation is partially associated with cell growth beginning during the lag phase, which lasts around 30 hours and can be related to the maintenance of the cells in the G1 phase by PMA. The larger cytokine production before cell doubling is in accordance with in vivo behavior, since the IL-2 released by T CD4+ cells peaks from 8 to 12 hours after cell activation (Abbas et al., 2000).

Despite inducing high IL-2 production, increasing the inoculum concentration resulted in diminished cell viability, possibly due to the fast consumption of substrates with the rapid formation of deleterious compounds. In response to these results, and in an attempt to reach a compromise between cell viability and IL-2 formation, cell concentration was maintained at $1.0^{*} 10^{6}$ cell $/ \mathrm{mL}$ in the subsequent experiments.

\section{Extended Studies of the Effects of PMA Concentration and Percentage of FCS on Cell Growth, Viability, and IL-2 Production}

Despite the fact that high PMA concentration decreased cell viability, the concentration range was extended to 10 to $1000 \mathrm{ng} / \mathrm{mL}$ in this set of experiments, aiming at higher IL-2 production. FCS range was maintained at 0 to $10 \%(\mathrm{v} / \mathrm{v})$, due to the fact that higher FCS concentration increases significantly the cost of culture medium and interferes with the purification stage. A $2^{2}$ factorial experimental design with four axial center points and 
four replicates at the center point, in a total of 12 experiments, was employed. The results are shown in Table 2.

The highest IL-2 concentration, around 162 $\mathrm{ng} / \mathrm{mL}$, was obtained in experiment 2 in a medium containing $856 \mathrm{ng} / \mathrm{ml}$ of PMA and $1.45 \%$ of FCS. The total cell concentration after $40 \mathrm{~h}$ varied only from $0.88 * 10^{6}$ to $1.74 * 10^{6}$ cell $/ \mathrm{mL}$, which can be related to the PMA effect of arresting cells in the G1 phase of cell growth. Cell viability varied from 31 to $60 \%$, with a central points average of $36.3 \pm 2.1 \%$. Figure 3 shows the effects of the independent variables on IL-2 concentration and cell viability.

PMA and FCS concentrations (linear terms) were statistically significant at a confidence level of $95 \%$ in IL-2 amounts released by EL-4 cells. The increase in PMA concentration in the culture medium results in an increase in IL-2 production, whilst the increase in percentage of FCS results in a decrease in IL-2 concentration in the cell cultures. In the previously used experimental design, FCS concentration had shown a positive effect on IL-2 concentration. The interaction term was significant at a confidence level of $89 \%$, revealing a negative effect on IL-2 production. The $p$-value showed that quadratic terms were not statistically significant.

There was a slight decrease in cell viability with the increase in PMA concentration at a confidence level of $90 \%$. The increase in FCS concentration again showed a negative effect (confidence level of
$95 \%$ ), which may be due to the observation of cell viability only after $40 \mathrm{~h}$. The quadratic terms were statistically significant (confidence level of 95\%), but the interaction term was not.

Supplementary experiments showed that low concentrations of FCS in the culture medium are required for the production of more elevated levels of IL-2 (data not shown). In the absence of FCS, there was a lower level of IL-2 production than that obtained in these experiments, even for concentrations of PMA up to $2000 \mathrm{ng} / \mathrm{mL}$.

Although it is not possible to directly compare the IL-2 production data presented herein to data from the literature, the behavior of EL-4 cells obeyed the same patterns as that reported by other authors (Farrar et al., 1980; Lasek et al., 1989; Dong et al., 1994; Yu et al., 1996). The direct comparison of IL-2 concentration is not recommended because most of the previous work discusses IL-2 production in terms of activity assessed by bioassays, and not in terms of concentration $(\mathrm{ng} / \mathrm{mL})$ as in the immunoassays carried out in this work. However, Farrar et al. (1980) achieved 5462.4 units of IL-2 activity per milliliter with EL-4 cells, which would be equivalent to around $27 \mathrm{ng} / \mathrm{mL}$ according to the international standard of NIBSC/WHO (National Institute for Biological Standards and Control/World Health Organization). In our study, up to $162 \mathrm{ng} / \mathrm{mL}$ of IL-2 accumulated in the culture medium; however, the IL2 bioactivity was not determined.

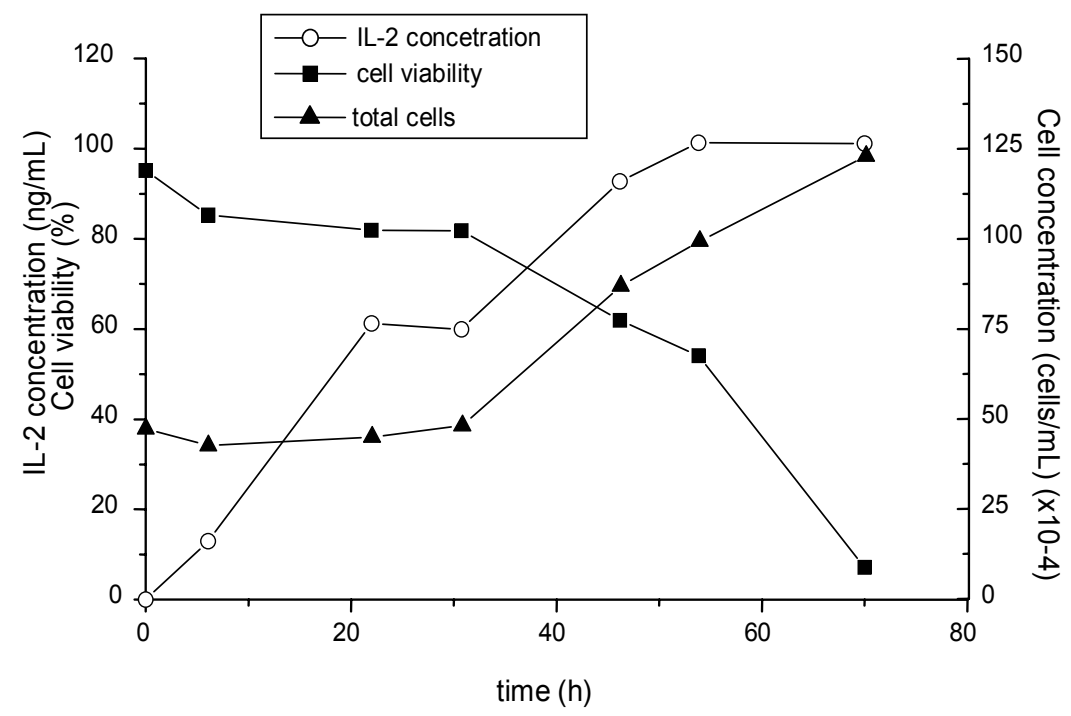

Figure 2: Evaluation of cell concentration, cell viability, and IL-2 production during culture of $4.5^{*} 10^{5}$ cells $/ \mathrm{mL}$ in RPMI-1640 supplemented with $5 \%$ (v/v) FCS, $505 \mathrm{ng} / \mathrm{mL}$ PMA, $0.2 \%(\mathrm{w} / \mathrm{v})$ Pluronic F68, $0.3 \mathrm{~g} / \mathrm{L}$ glutamine, and $50 \mu \mathrm{g} / \mathrm{mL}$ of gentamicin. 
Table 2: $2^{2}$ factorial experimental design with four axial center points and four replicates of the center point. The minimum medium formulation was RPMI-1640 supplemented with $50 \mu \mathrm{g} / \mathrm{mL}$ of gentamicin. Percentage of Pluronic F68 and glutamine and cell concentrations were maintained constant at $0.2 \%, 0.3 \mathrm{~g} / \mathrm{L}$, and $1.0 * 10^{6}$ cells $/ \mathrm{mL}$, respectively.

\begin{tabular}{|c|c|c|c|c|c|}
\hline Exp. & $\begin{array}{c}\text { PMA } \\
(\mathrm{ng} / \mathrm{mL})\end{array}$ & $\begin{array}{l}\text { FCS } \\
(\%)\end{array}$ & $\begin{array}{c}\text { IL-2 } \\
\text { concentration } \\
(\mathbf{n g} / \mathbf{m L})\end{array}$ & $\begin{array}{c}\text { Final cell } \\
\text { concentration } \\
(\text { cells } / \mathbf{m L})\end{array}$ & $\begin{array}{c}\text { Final cell } \\
\text { viability } \\
(\%)\end{array}$ \\
\hline 1 & 154 & 1.45 & 123.83 & $1.57 * 10^{6}$ & 50 \\
\hline 2 & 856 & 1.45 & 162.25 & $1.31 * 10^{6}$ & 60 \\
\hline 3 & 154 & 8.55 & 75.44 & $1.26^{*} 10^{6}$ & 30 \\
\hline 4 & 856 & 8.55 & 94.68 & $1.08 * 10^{6}$ & 39 \\
\hline 5 & 10 & 5.00 & 67.33 & $1.54 * 10^{6}$ & 49 \\
\hline 6 & 1000 & 5.00 & 134.41 & $0.88^{*} 10^{6}$ & 46 \\
\hline 7 & 505 & 0.00 & 117.18 & $1.22 * 10^{6}$ & 52 \\
\hline 8 & 505 & 10.00 & 81.92 & $1.43 * 10^{6}$ & 31 \\
\hline 9 & 505 & 5.00 & 106.62 & $1.42 * 10^{6}$ & 38 \\
\hline 10 & 505 & 5.00 & 107.27 & $1.16^{*} 10^{6}$ & 37 \\
\hline 11 & 505 & 5.00 & 110.67 & $1.74 * 10^{6}$ & 37 \\
\hline 12 & 505 & 5.00 & 100.79 & $1.24 * 10^{6}$ & 33 \\
\hline
\end{tabular}

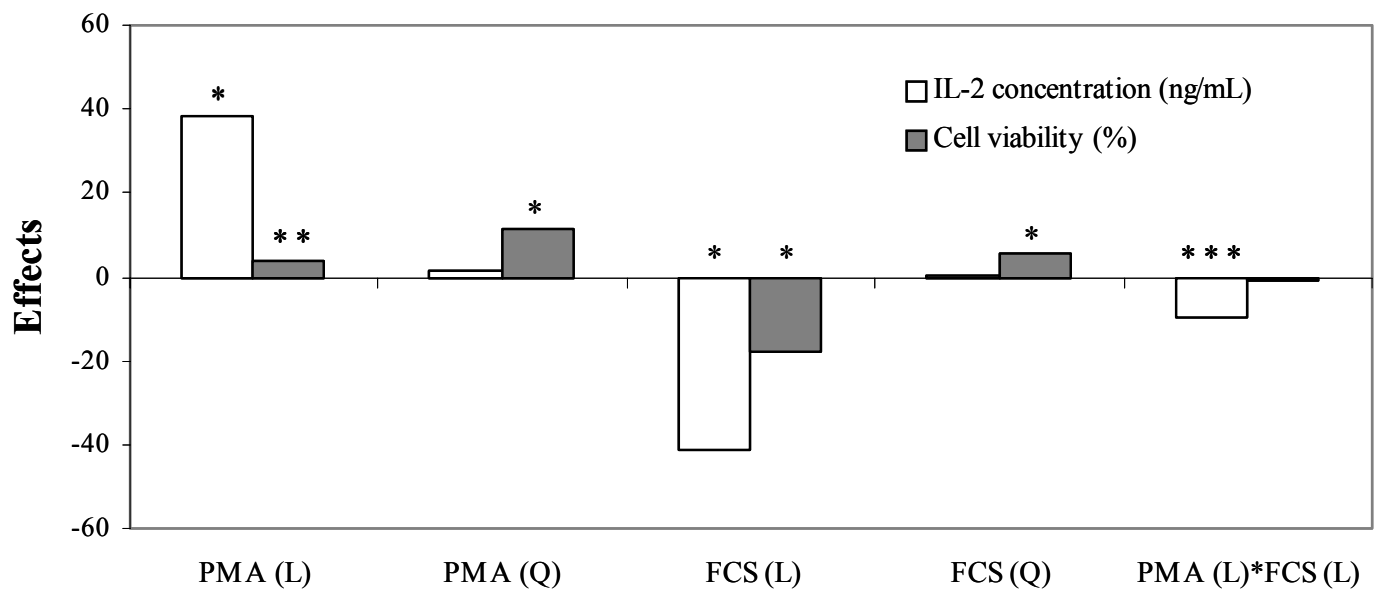

Figure 3: Effects obtained for the $2^{2}$ factorial experimental design on cell viability and IL-2 concentration.

The minimum medium formulation was RPMI-1640 supplemented with $50 \mu \mathrm{g} / \mathrm{mL}$ of gentamicin. Initial cell concentration, percentage of Pluronic F68, and glutamine concentration were maintained constant at $1.0 * 10^{6}$ cells $/ \mathrm{mL}, 0.2 \%$, and $0.3 \mathrm{~g} / \mathrm{L}$, respectively. * indicates that the variable is statistically significant at a confidence level of $95 \%$. ** indicates that the variable is statistically significant at a confidence level of $90 \%$. $* * *$ indicates that the variable is statistically significant at a confidence level of $89 \%$. L refers to linear and Q refers to quadratic effects. 
Evaluation of the Synergetic Effects of Con A with PMA and FCS

The effect of another stimulant, Con A, in association with PMA, on IL-2 production was evaluated based on the observations of Lasek et al. (1989), who obtained high IL-2 activity with a medium containing both stimulants simultaneously. A $2^{3}$ experimental design with six axial center points and four replicates at the center point was employed. Based on the results obtained by Lasek et al. (1989), the selected range of Con A concentration was 0 to $2.5 \mu \mathrm{g} / \mathrm{mL}$. The PMA concentration range was extended to 500 to $2000 \mathrm{ng} / \mathrm{mL}$ and percentage of FCS was reduced to 0 to $3 \%(\mathrm{v} / \mathrm{v})$, because the previous experimental design indicated that an increase in PMA concentration and a reduction in percentage of FCS could result in higher IL-2 production.

The results obtained in this set of experiments for IL-2 concentration and cell viability were below those achieved previously when only PMA and FCS effects were evaluated (Table 3). The maximum cell concentration attained was $1.83 * 10^{6}$ cell $/ \mathrm{mL}$. The statistical treatment of the data resulted in the effects shown in Figure 4.

The variation in PMA concentration from 500 to $2000 \mathrm{ng} / \mathrm{mL}$ did not have a significant effect on IL-2 production. An increase in Con A and FCS concentrations brought about a similar increase of 9.45 and $8.50 \mathrm{ng} / \mathrm{mL}$, respectively, in IL-2 concentration. Interaction terms did not show significance at a confidence level of $90 \%$, showing that these stimulants did not have a synergetic effect on IL-2 production by this cell line for the concentration ranges employed.

Concerning cell viability, the effect of PMA concentration and the effect of the interaction between PMA and FCS had statistical significance at a confidence level of $90 \%$. The increase in PMA concentration caused an increase in cell viability, and the interaction term showed a negative effect on this variable.

Table 3: $2^{3}$ factorial experimental design with six axial center points and four replicates of the center point. The minimum medium formulation was RPMI-1640 supplemented with $50 \mu \mathrm{g} / \mathrm{mL}$ of gentamicin. Percentage of Pluronic F68 and glutamine and cell concentrations were maintained constant at $0.2 \%, 0.3 \mathrm{~g} / \mathrm{L}$, and $1.0^{*} 10^{6}$ cells $/ \mathrm{mL}$, respectively.

\begin{tabular}{|c|c|c|c|c|c|c|}
\hline Exp. & $\begin{array}{c}\text { PMA } \\
\text { (ng/mL) }\end{array}$ & $\begin{array}{c}\text { Con A } \\
(\mu \mathrm{g} / \mathrm{mL})\end{array}$ & $\begin{array}{l}\text { FCS } \\
(\%)\end{array}$ & $\begin{array}{c}\text { IL-2 } \\
\text { concentration } \\
(\mathrm{ng} / \mathrm{mL})\end{array}$ & $\begin{array}{c}\text { Final cell } \\
\text { concentration } \\
(\text { cells } / \mathbf{m L})\end{array}$ & $\begin{array}{c}\text { Final cell } \\
\text { viability } \\
(\%)\end{array}$ \\
\hline 1 & 804 & 0.51 & 0.61 & 72.22 & $1.31 * 10^{6}$ & 18 \\
\hline 2 & 1696 & 0.51 & 0.61 & 66.78 & $1.44 * 10^{6}$ & 29 \\
\hline 3 & 804 & 1.99 & 0.61 & 90.03 & $1.40^{*} 10^{6}$ & 13 \\
\hline 4 & 1696 & 1.99 & 0.61 & 83.14 & $1.43^{*} 10^{6}$ & 29 \\
\hline 5 & 804 & 0.51 & 2.39 & 77.04 & $1.56^{*} 10^{6}$ & 19 \\
\hline 6 & 1696 & 0.51 & 2.39 & 74.24 & $1.28 * 10^{6}$ & 22 \\
\hline 7 & 804 & 1.99 & 2.39 & 77.92 & $1.71 * 10^{6}$ & 22 \\
\hline 8 & 1696 & 1.99 & 2.39 & 79.83 & $1.56^{*} 10^{6}$ & 25 \\
\hline 9 & 500 & 1.25 & 1.50 & 72.22 & $1.51 * 10^{6}$ & 10 \\
\hline 10 & 2000 & 1.25 & 1.50 & 76.40 & $1.37 * 10^{6}$ & 37 \\
\hline 11 & 1250 & 0.00 & 1.50 & 80.47 & $1.51 * 10^{6}$ & 20 \\
\hline 12 & 1250 & 2.50 & 1.50 & 94.63 & $1.46^{*} 10^{6}$ & 21 \\
\hline 13 & 1250 & 1.25 & 0.00 & 45.36 & $0.95 * 10^{6}$ & 30 \\
\hline 14 & 1250 & 1.25 & 3.00 & 81.74 & $1.51 * 10^{6}$ & 23 \\
\hline 15 & 1250 & 1.25 & 1.50 & 76.27 & $1.24 * 10^{6}$ & 26 \\
\hline 16 & 1250 & 1.25 & 1.50 & 81.74 & $1.83 * 10^{6}$ & 19 \\
\hline 17 & 1250 & 1.25 & 1.50 & 87.86 & $1.31 * 10^{6}$ & 26 \\
\hline 18 & 1250 & 1.25 & 1.50 & 77.04 & $1.58 * 10^{6}$ & 24 \\
\hline
\end{tabular}




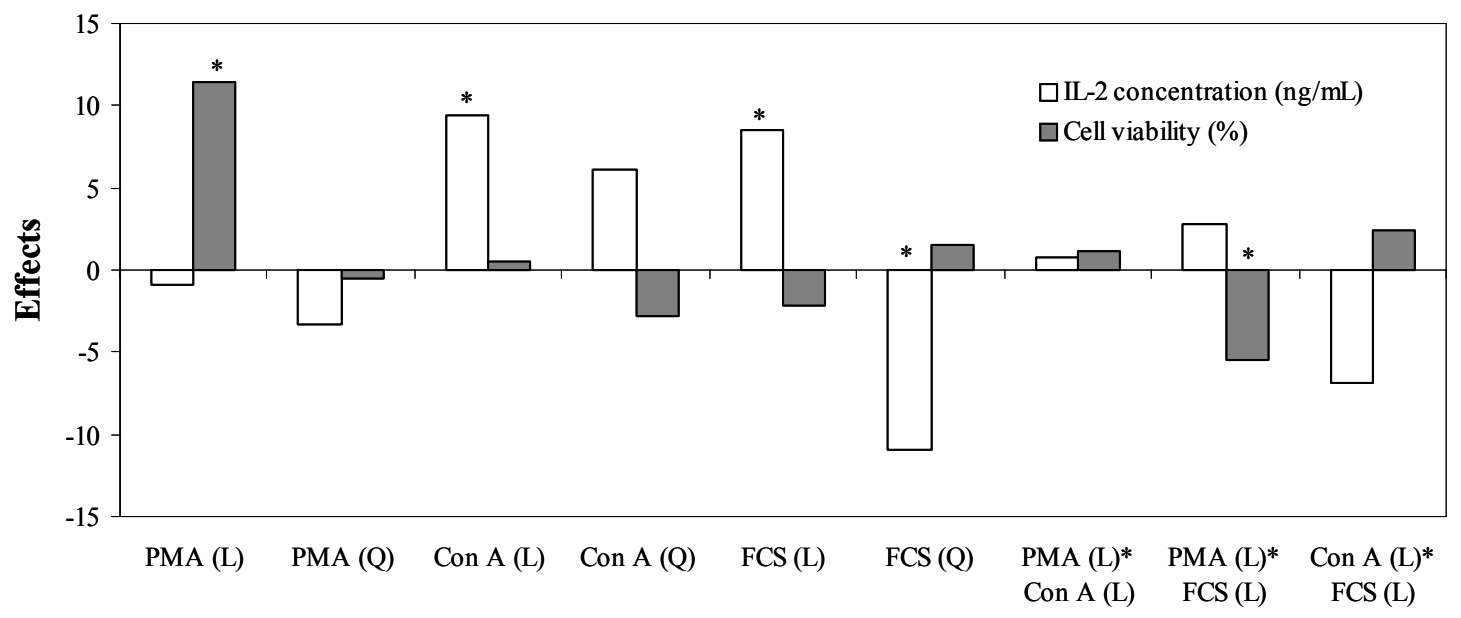

Figure 4: Effects obtained for the $2^{3}$-factorial experimental design. The minimum medium formulation was RPMI-1640 supplemented with $50 \mu \mathrm{g} / \mathrm{mL}$ of gentamicin. Cell concentration, percentage of Pluronic

F68, and glutamine concentration were maintained constant at $1.0^{*} 10^{6}$ cells $/ \mathrm{mL}, 0.2 \%$, and $0.3 \mathrm{~g} / \mathrm{L}$ respectively. * indicates that the variable is statistically significant at a confidence level of $90 \%$.

\section{CONCLUSIONS}

From the results obtained it can be observed that glutamine concentration and percentage of Pluronic F68 did not have significant effects on IL-2 production and cell viability. The highest IL-2 concentration occurred, in general, for an initial cell concentration of $1.0^{*} 10^{6}$ cell $/ \mathrm{mL}$. The independent variables that most influenced IL-2 production were PMA concentration and percentage of FCS. An IL-2 concentration of $162 \mathrm{ng} / \mathrm{mL}$ was attained when 856 $\mathrm{ng} / \mathrm{mL}$ PMA and $1.45 \%(\mathrm{v} / \mathrm{v})$ FCS were present in the culture medium. The addition of PMA in association with Con A was less efficient than the addition of PMA alone. These stimulants did not have a synergetic effect in the concentration ranges studied.

\section{REFERENCES}

Abbas, A.K., Lichtman, A.H. and Pober, J.S., Cellular and Molecular Immunology. $4^{\text {th }}$ edition, W. B. Saunders, Philadelphia, 553 p. (2000).

Chang, A.E., Lotze, M.T., Ames, R.S., Roth, J.A. and Rosenberg, S.A., A Large Scale Method of Separating Multiple Lymphokines Secreted by the Murine EL-4 Thymoma. Journal of Immunopharmacology, 7 (1), 17-31 (1985).

Dong, W., Azcona-Oliveira, J.I., Brooks, K.H., Linz, J.E. and Pestka, J.J., Elevated Gene Expression and Production of Interleukins 2, 4, 5 and 6 during Exposure to Vomitoxin (Deoxynivalenol) and Cycloheximide in the EL-4 Thymoma. Toxicology and Applied Pharmacology, 127, 282-290 (1994).

Farrar, J.J., Fuller-Farrar, J., Simon, P.L., Hilfiker, M.L., Stadler, B.M. and Farrar, W.L., Thymoma Production of T Cell Growth Factor (Interleukin2). Journal of Immunology, 125, 2555-2558 (1980).

Fehniger, T.A., Cooper, M.A. and Caligiuri, M.A., Interleukin-2 and Interleukin-15: Immunotherapy for Cancer. Cytokine \& Growth Factor Reviews, 13, 169-183 (2002).

Freshney, R.I., Culture of Animal Cells - A Manual of Basic Technique. $3^{\text {rd }}$ edition, Wiley-Liss, New York, 486 p. (1994).

Lasek, W., Steer, S., Clothier, R. and Balls, M., The Stimulation of EL-4 Cells to Produce Interleukin2 and Its Potential Use in Immunocytotoxicity Testing. Immunopharmacology and Immunotoxicology, 11 (2-3), 379-396 (1989).

Rosenberg, S.A., Mule, J.J., Spiess, P.J., Reichert, C.M. and Schwarz, S.L., Regression of Established Pulmonary Metastases and Subcutaneous Tumor Mediated by the Systemic Administration of High-dose Recombinant Interleukin 2. Journal of Experimental Medicine, 161 (5), 1169-1188 (1985a).

Rosenberg, S.A., Lotze, M.T., Muul, L.M., Leitman, S., Chang, A.E., Ettinghausen, S.E., Matory, Y.L., Skibber, J.M., Shiloni, E., Vetto, J.T., Seipp, C.A., Simpson, C. and Reichert, C.M., 
Observations on the Systemic Administration of Autologous Lymphokine-activated Killer Cells and Recombinant Interleukin-2 to Patients with Metastatic Cancer. New England Journal of Medicine, 313 (23), 1485-1492 (1985b).

Stites, D.P., Terr, A.I. and Parslow, T.G., Basic and Clinical Immunology. $8^{\text {th }}$ edition, Prentice-Hall International, Norwalk, 870 p. (1994).

Walsh, G. and Headon, D., Protein Biotechnology. John Wiley \& Sons, Chichester, 371 p. (1994).
Weinreich, D.M. and Rosenberg, S.A., Response Rates of Patients with Metastatic Melanoma to High-dose Intravenous Interleukin-2 after Prior Exposure to Alpha-Interferon or Low-dose Interleukin-2. Journal of Immunotherapy, 25 (2), 185-187 (2002).

Yu, W., Sanders, B.G. and Kline, K., Modulation of Murine EL-4 Thymic Lymphoma Cell Proliferation and Cytokine Production by Vitamin E Succinate. Nutrition and Cancer - An International Journal, 25, 137-149 (1996). 